\title{
Tariffs Ranking in Mixed Oligopoly with Revenue Constraint
}

\author{
Leonard F. S. Wang, ${ }^{1}$ Jean Wang, ${ }^{2}$ Long Tang, ${ }^{3}$ and Jen-Yao Lee ${ }^{4}$ \\ ${ }^{1}$ Department of Applied Economics, National University of Kaohsiung, Kaohsiung 41148, Taiwan \\ ${ }^{2}$ Economics Division, SinoAsia Economic and Management Foundation, Kaohsiung 41148, Taiwan \\ ${ }^{3}$ Hanqing Advanced Institute of Economic and Finance, Renmin University of China, Beijing 100872, China \\ ${ }^{4}$ Department of International Business, National Kaohsiung University of Applied Science, Kaohsiung 80778, Taiwan
}

Correspondence should be addressed to Leonard F. S. Wang, lfswang@nuk.edu.tw

Received 3 December 2010; Revised 28 June 2011; Accepted 29 June 2011

Academic Editor: Yew-Kwang Ng

Copyright ( 12011 Leonard F. S. Wang et al. This is an open access article distributed under the Creative Commons Attribution License, which permits unrestricted use, distribution, and reproduction in any medium, provided the original work is properly cited.

\begin{abstract}
Utilizing linear mixed oligopoly model, this paper explores the magnitude of the maximum-revenue tariff, optimum-welfare tariff, and revenue-constrained optimal tariff that is especially designed for the consideration of the bureaucratic inefficiency. In particular, the tariff ranking issue is examined under both cases of Cournot competition and domestic public leadership. We found that, under Cournot competition, the optimum-welfare tariff is the highest and it is followed by the revenue-constrained optimal tariff while the maximum-revenue tariff is the lowest. But, under Stackelberg public leadership, if the domestic private firms are fewer than the foreign firms, the maximum-revenue tariff becomes the highest and the optimum-welfare exceeds the revenue-constrained optimal tariff.
\end{abstract}

\section{Introduction}

Whether to apply maximum revenue tariffs or optimum welfare tariffs is interesting and should be deliberated because the tariff revenue is an important income source of a government before building up an efficient tax system. However, a government may adjust its goal from maximumrevenue to optimum-welfare along with economic improvement and the need for fiscal reform.

In traditional tariff analyses, Johnson [1] argued that the maximum-revenue tariff is higher than the optimumwelfare tariff because a "large" country could change the terms of trade in order to raise its social welfare. From the strategic trade aspect, Brander and Spencer [2] showed that a government could improve its terms of trade through using tariff as a strategic instrument in an oligopoly market to take a leading position for transferring foreign firm's revenue to a domestic firm. Collie [3] demonstrated that, in a Cournot duopoly market with linear demand and an asymmetric constant marginal cost, the optimum welfare tariff exceeds the maximum revenue if the domestic and foreign firm's marginal costs are equal. Larue and Gervais [4] allowed an asymmetric number of domestic and foreign firms and showed that, if the numbers of domestic firms and foreign firms are the same, the maximum-revenue tariff is higher than the optimum-welfare tariff. Clarke and Collie [5] found that, in a Bertrand competition model, the optimum-welfare tariff is higher than the maximum-revenue tariff when the products are highly substitutable. Wang et al. [6] introduced market share delegation in a trade duopoly context and demonstrated that the home government unambiguously imposes a higher optimum-welfare tariff than maximumrevenue one regardless of the form of delegation. Wang et al. [7-9] reexamined the tariff ranking issue under a linear mixed oligopoly model with foreign competitors and asymmetric costs (Maw [10] reviewed the empirical evidence and justified the adoption of partial privatization in transitional economies. Chang [11] adopted Matsumura's [12] model to analyze the optimal trade and privatization policies in an international mixed duopoly with cost asymmetry while Chao and $\mathrm{Yu}$ [13] examined the effect of partial privatization or foreign competition on optimal tariffs and found that foreign competition lowers the optimal tariff rate but partial privatization raises it. Van Long and Stähler [14] recently established a mixed duopoly model with partial privatization to discuss how state ownership impacts the optimal import 
tariff and export subsidy. The above papers concern how the degree of partial privatization affects optimal tariff but not the revenue-maximum tariff.) In particular, they demonstrated that, under Cournot competition, when the domestic private and foreign private firms become more unequally distributed, the optimum-welfare tariff exceeds the maximum-revenue tariff. Wang and Lee [7] revealed that, in an international mixed oligopoly with asymmetric costs and partial privatization, when the marginal cost of the privatized firm exceeds a critical value, the maximum-revenue tariff is higher than the optimum-welfare tariff. Wang et al. [15] further explored tariffs ranking under Cournot and two Stackelberg cases and found that, in an international mixed duopoly, the optimum-welfare tariff will be lower than the maximum-revenue one regardless of the order of firm's move when the marginal cost of the privatized firm is higher than a critical value; furthermore, if the degree of privatization is sufficiently high and the domestic firm is highly ineffective in production, then it is more possible that the optimumwelfare tariff is lower than the maximum-revenue tariff when the public firm is the leader in the Stackelberg market.

Early studies of mixed oligopolistic markets $[16,17]$ were based on the framework in which welfare-maximizing public firm competes against profit-maximizing private firms in a closed economy (See Katsoulacos [18] for rationalizing the firms' objectives in transitional economies, and Fjell and Pal [19] and Pal and White [20] on modeling mixed oligopoly that includes both domestic and foreign private firms. Also see Bárcena-Ruiz and Garzón [21] and Matsushima and Matsumura [22] introducing the mixed oligopoly model into the field of environmental policy and location choice, resp.) In the real world, along with the wave of trade liberalization, the situation of more foreign firms entering the domestic market is prevalent. The modeling of mixed oligopoly with foreign competitors began with Fjell and Pal [19], who studied the effects of introducing foreign private firms on equilibrium price and allocation of production. In a seminal paper, $\mathrm{Pal}$ and White [20] explored the interactions between privatization and strategic trade policies with and without efficiency gain. Fjell and Heywood [23] examined the equilibrium effects under Stackelberg public leadership and discussed the effects of allowing foreign firms to enter the domestic market, while Matsumura [24] studied the endogenous timing of a mixed duopoly and showed that the public firm evolves to become the leader in the presence of foreign competition.

Leahy and Montagna [25] examined strategic trade policy under a heterogeneous cost oligopoly and showed that the government favors the most efficient firms only with a sufficiently low social cost of public funds. Neary and Leahy [26] characterized optimal revenue-constrained trade and industrial policy towards dynamic oligopolies and proved that total net subsidy payments at the optimum decrease with the social cost of public funds. Hatta and Ogawa [27] examined the optimal tariff structure under a revenue constraint and showed that the revenue-constrained optimal tariff structure is characterized by two rules: (i) the optimal tariff rate is lower for the import good that is a closer substitute for the export good and (ii) the stronger the crosssubstitutability between imports, the closer the optimal tariff is to uniformity (There is literature related to the competition policy implication of tariffs like Yano et al. [28], who demonstrated that the common wisdom saying that competition policy is at best the second best in serving as a substitute for tariff policy that creates a beggar-thy-neighbor effect no longer holds if a country can impose a tariff on only a part of the entire spectrum of imports, and consequently, tariff policy may not be as effective a beggar-thy-neighbor policy as competition policy.) Though the mentioned studies explored the implications of revenue constraint on strategic subsidy or optimal tariff or even questioned the effectiveness of tariff policy as a competition policy, those works failed to consider public firms in the context of international mixed oligopoly.

In this paper, we explore the magnitude of the maximum-revenue tariff, optimum-welfare tariff, and revenueconstrained optimal tariff that specially considers the bureaucratic inefficiency. In particular, we examine the tariff ranking issue under both cases of Cournot competition and domestic public leadership. We found that, under Cournot competition, irrelevant of the firms' distribution between the domestic and the foreign firms, the optimum-welfare tariff is the highest with the revenue-constrained optimal tariff followed by the maximum revenue tariff which is the lowest. On the contrary, under Stackelberg public leadership, if the domestic private firms are fewer than the foreign firms, the maximum-revenue tariff becomes the highest followed by the optimum-welfare tariff and the revenue-constrained optimal tariff turns out to be the lowest.

The rest of this paper is organized as follows. Basic modeling is provided in Section 2. Section 3 contains the analysis of tariff ranking. Section 4 concludes the paper.

\section{Basic Modeling}

Consider a domestic market for a homogeneous good produced by 1 public firm, $n$ domestic private firms, and $m$ foreign private firms. The output of the public firm, $i$ th domestic private firm, and $j$ th foreign private firm are, respectively, denoted by $q_{0}, q_{i}^{d}, i=(1, \ldots, n)$, and $q_{j}^{f}, j=$ $(1, \ldots, m)$, while the marginal costs of those firms are $c_{0}, c_{i}^{d}$ and $c_{j}^{f}$, respectively (When $c_{i}^{d} \leq c_{j}^{f}$, no foreign private firms will produce and export to domestic country. See also Huang et al. [29] for the extended specification.) The total output is given by $Q=q_{0}+\sum_{i=1}^{n} q_{i}^{d}+\sum_{j=1}^{m} q_{j}^{f}$, and the linear demand function is $p=a-q_{0}-\sum_{i=1}^{n} q_{i}^{d}-\sum_{j=1}^{m} q_{j}^{f}$.

The profits of public firm, domestic private firms, and foreign private firms are given by:

$$
\begin{aligned}
& \pi_{0}=\left[a-\left(q_{0}+\sum_{i=1}^{n} q_{i}^{d}+\sum_{j=1}^{m} q_{j}^{f}\right)\right] q_{0}-c_{0} q_{0}, \\
& \pi_{i}^{d}=\left[a-\left(q_{0}+\sum_{i=1}^{n} q_{i}^{d}+\sum_{j=1}^{m} q_{j}^{f}\right)\right] q_{i}^{d}-c_{i}^{d} q_{i}^{d}, \\
& \pi_{j}^{f}=\left[a-\left(q_{0}+\sum_{i=1}^{n} q_{i}^{d}+\sum_{j=1}^{m} q_{j}^{f}\right)\right] q_{j}^{f}-c_{j}^{f} q_{j}^{f}-t q_{j}^{f} .
\end{aligned}
$$


The domestic government imposes a specific tariff on the foreign firms with the tariff rate $t$, and that brings tariff revenue $R=t \sum_{j=1}^{m} q_{j}^{f}$ to the government. The social welfare is defined as

$$
W=C S+\pi_{0}+\sum_{i=1}^{n} \pi_{i}^{d}+t \sum_{j=1}^{m} q_{j}^{f},
$$

where the consumer surplus is given by $C S=(1 / 2)\left(q_{0}+\right.$ $\left.\sum_{i=1}^{n} q_{i}^{d}+\sum_{j=1}^{m} q_{j}^{f}\right)^{2}$.

The revenue-constrained social welfare is then defined as

$$
R W=C S+\pi_{0}+\sum_{i=1}^{n} \pi_{i}^{d}+\delta t \sum_{j=1}^{m} q_{j}^{f},
$$

where $\delta$ signifies the social cost of public fund for representing administrative inefficiency of government bureaucracy. The range of parameter $\delta$ is $\delta \leq 1$ meaning that the lower the $\delta$ is, the higher the social cost is. (See Leahy and Montagna [25] and Neary and Leahy [26] for the specification where $\delta$ is the marginal social cost of funds. Neary and Leahy [26] argue that $\delta$ is normally greater than unity which is different from our specification but the economics intuition is the same.) The difference between $W$ and $R W$ is $(1-\delta) t \sum_{j=1}^{m} q_{j}^{f}$. Note that (2) and (3) represent the objective functions of the government depending on the goal the government pursues.

In this model, backward induction is used to solve the subgame perfect Nash equilibrium.

\section{Tariff Ranking Analysis}

In this section, the ranking of revenue-constrained optimal tariff, optimum-welfare tariff, and maximum-revenue tariff under linear mixed oligopoly is explored. The cases of Cournot competition and Stackelberg public leadership under constant marginal costs are examined to see whether the order of firms' move influences the ranking of revenueconstrained optimal tariff, optimum-welfare tariff, and maximum-revenue tariff. The marginal costs for the public firm and both the domestic and foreign private firms are $c_{0}$ and $c \equiv c_{i}^{d} \equiv c_{j}^{f}$, respectively. The private firms are more efficient than the public firm, namely, $c<c_{0}$.

3.1. Case: Cournot Competition. In the 2 nd stage, the $(m+$ n) private firms maximize their profits and the public firm maximizes social welfare then; from the first-order conditions, $\partial W / \partial q_{0}=0, \partial \pi_{i}^{d} / \partial q_{i}^{d}=0$, and $\partial \pi_{j}^{f} / \partial q_{j}^{f}=0$, we have that

$$
\begin{aligned}
& q_{0}(t)=a-c_{0}-\frac{n\left(c_{0}-c+m t\right)}{1+m}, \\
& q_{i}^{d}(t)=\frac{c_{0}-c+m t}{1+m}, \\
& q_{j}^{f}(t)=\frac{c_{0}-c-t}{1+m} .
\end{aligned}
$$

Equation (4) shows that when $c_{0}<[a+c n+m(a-$ $n t)] /(1+m+n), q_{0}$ is positive. In addition, when $t \geq c_{0}-c$, $q_{j}^{f}=0$, the tariff rate is $t=c_{0}-c$.
In the 1st stage, the domestic government maximizes social welfare, revenue-constrained social welfare, or tariff revenue.

If the domestic government maximizes social welfare, we obtain

$$
\begin{aligned}
\frac{d W}{d t}= & Q\left[\frac{d q_{0}}{d t}+n \frac{d q_{i}^{d}}{d t}+m \frac{d q_{j}^{f}}{d t}\right]+\left[q_{0} \frac{d p}{d t}+\left(p-c_{0}\right) \frac{d q_{0}}{d t}\right] \\
& +n\left[q_{i}^{d} \frac{d p}{d t}+(p-c) \frac{d q_{i}^{d}}{d t}\right]+m\left[q_{j}^{f}+t \frac{d q_{j}^{f}}{d t}\right] .
\end{aligned}
$$

If the domestic government maximizes revenue-constrained social welfare, we have

$$
\begin{aligned}
\frac{d R W}{d t}= & Q\left[\frac{d q_{0}}{d t}+n \frac{d q_{i}^{d}}{d t}+m \frac{d q_{j}^{f}}{d t}\right] \\
& +\left[q_{0} \frac{d p}{d t}+\left(p-c_{0}\right) \frac{d q_{0}}{d t}\right] \\
& +n\left[q_{i}^{d} \frac{d p}{d t}+(p-c) \frac{d q_{i}^{d}}{d t}\right]+\delta m\left[q_{j}^{f}+t \frac{d q_{j}^{f}}{d t}\right] .
\end{aligned}
$$

In (5), the first term is consumer surplus effect; if it is negative, it means increasing tariff will decrease consumer surplus. It is first because of $\left(d q_{s} / d t\right)+n\left(d q_{i} / d t\right)=0$ in the first term, which is due to $n q_{i}^{*}+q_{s}^{*}=a-c_{s}$ as well as that the total output of public firm and domestic private firms is constant and not affected by $m$ and $t$, and the second reason is due to the negative relationship between the tariff and the quantity imported from foreign firms. These two reasons make the consumer surplus effect represented by the whole first term negative. The second and third terms denote the profit shifting effect. The public firm may continue to produce until its profit becomes negative (when $n=0, p<0$ ), and the impact of tariff on its profit is ambiguous. The third term is positive simply because tariff raises the marginal cost of the foreign firms resulting in the profit shifting from the foreign firms to the domestic private firms. The fourth term is the revenue effect which could either be positive or negative depending on the relative magnitude of consumer surplus effect and the profit shifting effect. Hence, when the fourth term is negative and the sum of consumer surplus effect and the profit shifting effect is positive, the optimum-welfare tariff exceeds the maximum-revenue tariff. Note that when $n=0$, tariff has negative impact on the public firm's profit in the second term and the third term is zero, so the profit shifting to the domestic firms is negative, but the revenue effect must be positive. In $\left(5^{\prime}\right)$, the revenue effect is smaller than that in (5) due to the social cost of public fund.

From (5) and $\left(5^{\prime}\right)$, we obtain that

$$
\begin{aligned}
t^{W C} & =\frac{\left(c_{0}-c\right)(1+n+m n)}{2+m}, \\
t^{R W C} & =\frac{\left(c_{0}-c\right)[n+\delta+m(n+\delta-1)]}{2(1+m) \delta-m},
\end{aligned}
$$


where " $C$ " denotes Cournot competition and (the secondorder condition guarantees that $2(1+m) \delta-m>0) . t^{W C}$ and $t^{R W C}$ are the optimum-welfare tariff and the revenueconstrained optimal tariff under Cournot competition, respectively. Differentiating $t^{R W C}$ with respect to $\delta$, we have

$$
\frac{\partial t^{R W C}}{\partial \delta}=\frac{(1+m)[m-2(1+m) n]\left(c_{0}-c\right)}{[m-2(1+m) \delta]^{2}}<0 .
$$

Lemma 1. The revenue-constrained optimal tariff is increasing with the higher social cost of public fund.

The revenue-constrained optimal tariff is increasing with the social cost of public fund because the government needs to raise the tariff rate to collect the planned tariff revenue. The reasoning for such results comes from two effects: firstly, the direct effect of the higher social cost reduces the tariff revenue; secondly, the indirect effect reflects a decrease in the consumer surplus effect and production substitution from foreign firm to domestic firms due to profit shifting effect.

Comparing these two tariff rates, we have

$$
t^{W C}-t^{R W C}=\frac{(1+m)[2(1+m) n-m](1-\delta)\left(c_{0}-c\right)}{(2+m)[2(1+m) \delta-m]} .
$$

We obtain that because $n>m / 2(1+m), t^{W C}>t^{R W C}$. And when $\delta=1, t^{W C}=t^{R W C}$.

Proposition 2. Under Cournot competition, the optimumwelfare tariff exceeds the revenue-constrained optimal tariff with the social cost of public fund.

If the government maximizes efficient tariff revenue, from $d R / d t=0$, we obtain

$$
t^{R C}=\frac{1}{2}\left(c_{0}-c\right),
$$

where " $R C$ " means maximum revenue under Cournot competition. Comparing the optimum-welfare tariff and the maximum-revenue tariff, we have

$$
t^{W C}-t^{R C}=\frac{[2(1+m) n-m]\left(c_{0}-c\right)}{2(2+m)}>0 .
$$

Corollary 3. Under Cournot competition, the optimumwelfare tariff exceeds the maximum-revenue tariff.

Corollary 3 is the special case of Wang et al. [7-9] when the costs of the domestic private and foreign firms are the same. The intuition behind Corollary 3 is that with the domestic private and foreign firm's competition, when the domestic government imposes a tariff, the public firm will further reduce its output when the public firm's marginal cost exceeds both domestic and foreign private firm's costs and then due to that, the profit shifting effect is less than the consumer surplus loss, so the domestic government imposes a higher optimum-welfare tariff, compared to the maximumrevenue tariff. This result modifies and strengthens the result obtained in Collie [3]; the optimum-welfare tariff exceeds the maximum-revenue tariff if the domestic and foreign firms' marginal costs are equal.

Next, we compare the revenue-constrained optimal tariff and the maximum-revenue tariff we have;

$$
t^{R W C}-t^{R C}=\frac{[2(1+m) n-m]\left(c_{0}-c\right)}{2[2(1+m) \delta-m]}>0 .
$$

Hence, from Proposition 2 and Corollary 3, we have $t^{W C}>t^{R W C}>t^{R C}$.

Proposition 4. Under Cournot competition, the optimumwelfare tariff is the highest and it is followed by the revenueconstrained optimal tariff while the maximum-revenue tariff is the lowest.

In $[3,4]$, whether the optimal welfare tariff is higher or lower than maximum revenue tariff under pure oligopoly depends on asymmetric cost and asymmetric number of firms. However, Proposition 4 indicates that the tariffs ranking is unidirectional and depends on the degree of revenue constraint as it is stated in Lemma 1.

3.2. Case: Stackelberg Public Leadership. In the 3rd stage, the $(n+m)$ private firms maximize their profits. Therefore, from the first-order conditions, $\partial \pi_{i}^{d} / \partial q_{i}^{d}=0$ and $\partial \pi_{j}^{f} / \partial q_{j}^{f}=0$, we have that

$$
\begin{aligned}
q_{i}^{d}\left(q_{0}, t\right) & =\frac{a-q_{0}-c+m t}{1+n+m}, \\
q_{j}^{f}\left(q_{0}, t\right) & =\frac{a-q_{0}-c-t-n t}{1+n+m} .
\end{aligned}
$$

In the 2nd stage, the public firm maximizes the social welfare; we have that

$$
q_{0}^{*}(t)=a-c_{0}-\frac{\left[2 n+(m+n)^{2}\right]\left(c_{0}-c\right)+m(1+2 n) t}{1+2 m} .
$$

In the 1st stage, the government maximizes social welfare or the revenue-constrained social welfare; from $d W / d t=0$ and $d R W / d t=0$, we obtain optimal tariff rates, respectively,

$$
\begin{aligned}
t^{W P} & =\frac{1}{2}(1+2 n)\left(c_{0}-c\right), \\
t^{R W P} & =\frac{\left(c_{0}-c\right)[n-m+(m+n+1) \delta]}{2 \delta},
\end{aligned}
$$

where " $P$ " denotes public leadership. $t^{W P}$ and $t^{R W P}$ are the optimum-welfare tariff and revenue-constrained optimal tariff under Stackelberg public leadership, respectively. Comparing these two tariff rates shows

$$
t^{W P}-t^{R W P}=\frac{(m-n)(1-\delta)\left(c_{0}-c\right)}{2 \delta} .
$$

We obtain that when $n<m, t^{W P}>t^{R W P}$; otherwise, $t^{W P} \leq t^{R W P}$. Thus, we have the following proposition. 
Proposition 5. Under Stackelberg public leadership, the optimum-welfare tariff exceeds the revenue-constrained optimal tariff if the domestic private firms are less than the foreign firms. Otherwise, the optimum-welfare tariff exceeds the revenueconstrained optimal tariff.

If the domestic government maximizes efficient tariff revenue, from $d R / d t=0$, we obtain that

$$
t^{R P}=\frac{(1+m+n)\left(c_{0}-c\right)}{2},
$$

where " $R P$ " denotes maximum revenue under Stackelberg public leadership. Comparing the optimum-welfare tariff and the maximum-revenue tariff, we have

$$
t^{W P}-t^{R P}=\frac{(n-m)\left(c_{0}-c\right)}{2} .
$$

We obtain that when $n<m, t^{W P}<t^{R P}$; otherwise, $t^{W P} \geq$ $t^{R P}$. Thus, we have the following corollary.

Corollary 6. Under Stackelberg public leadership, the maximum-revenue tariff exceeds the optimum-welfare tariff if the domestic private firms are less than the foreign firms.

Note that, in [4], if the numbers of domestic firms and foreign firms are the same, the maximum-revenue tariff is higher than the optimum-welfare tariff. In [7-9], however, because of the revenue effect that results from more foreign firms, the maximum-revenue tariff is higher than the optimum-welfare tariff if the number of foreign firms exceeds domestic private firms.

We then compare the revenue-constrained optimal tariff and the maximum-revenue tariff:

$$
t^{R P}-t^{R W P}=\frac{(m-n)(c-c)}{2 \delta} .
$$

We obtain that when $n<m, t^{R P}>t^{R W P}$; otherwise, $t^{R P} \leq$ $t^{R W P}$. From Proposition 5 and Corollary 6 , it is immediate that when $n<m, t^{R P}>t^{W P}>t^{R W P}$; otherwise, $t^{R P} \leq t^{W P} \leq$ $t^{R W P}$. We have the following proposition.

Proposition 7. Under Stackelberg public leadership, the maximum-revenue tariff is the highest with the optimumwelfare tariff followed by which the revenue-constrained optimal tariff is the lowest if the domestic private firms are fewer than the foreign firms.

Note that, under Cournot competition, we have $t^{W C}>$ $t^{R W C}>t^{R C}$. However, under Stackelberg public leadership with more foreign firms than domestic firms, the maximumrevenue tariff becomes the highest. It is due to the first mover advantage and production inefficiency of the public firm, the government needs to reduce the optimum-welfare tariff to avoid the production distortion and enhance the consumer surplus. Hence, we have $t^{R P}>t^{W P}>t^{R W P}$. If the domestic firms are more than the foreign firms, the production substitution occurs meaning that more output is produced by domestic firms; the optimum-welfare tariff will be higher; we then have $t^{R P} \leq t^{W P} \leq t^{R W P}$.

\section{Conclusions}

This paper proposed a viewpoint of tariff ranking that differs from Collie [3], who argued that when the marginal cost of the domestic firm is higher than that of the foreign firm under a pure Cournot duopoly market, the maximumrevenue tariff may be higher than the optimum-welfare tariff. In this paper, we explore the magnitude of the maximumrevenue tariff, optimum-welfare tariff, and the revenueconstrained optimal tariff that is specially designed for the consideration of the bureaucratic inefficiency. In particular, we examine the tariff ranking issue under both cases of Cournot competition and domestic public leadership.

The revenue-constrained optimal tariff increases with the higher social cost of public fund, and the government will need to raise the tariff rate to collect the planned tariff revenue. The reasoning for such results comes from two effects: firstly, the direct effect of the higher social cost that reduces the tariff revenue; secondly, the indirect effect reflects a decrease in the consumer surplus effect and the production substitution from the foreign firms to the domestic firms due to profit-shifting effect.

We found that, under Cournot competition, irrelevant of the firms' distribution between the domestic and the foreign firms, the optimum-welfare tariff is the highest with the revenue-constrained optimal tariff followed by the maximum-revenue tariff which is the lowest. On the contrary, under Stackelberg public leadership, if the domestic private firms are fewer than the foreign firms, the maximumrevenue tariff becomes the highest with the optimum-welfare tariff followed by the revenue-constrained optimal tariff which turns out to be the lowest.

\section{Acknowledgments}

The authors would like to thank the editor, Yew-Kwang $\mathrm{Ng}$, and two anonymous referees for their useful comments and suggestions. They would also like to thank Tien Der Han for his assistance when they revised the paper. The work described in this paper was supported by the National Science Council of Taiwan under Grant NSC 99-2410-H390-006-MY3.

\section{References}

[1] H. G. Johnson, "Optimum welfare and maximum revenue tariffs," Review of Economic Studies, vol. 19, pp. 28-35, 1952.

[2] J. A. Brander and B. J. Spencer, "Tariff protection and imperfect competition," in Monopolistic Competition and International Trade, H. Kierzkowski, Ed., pp. 194-207, Oxford University Press, Oxford, UK, 1984.

[3] D. R. Collie, "Optimum welfare and maximum revenue tariffs under oligopoly," Scottish Journal of Political Economy, vol. 38, pp. 398-401, 1991.

[4] B. Larue and J. P. Gervais, "Welfare-maximizing and revenuemaximizing tariffs with a few domestic firms," Canadian Journal of Economics, vol. 35, no. 4, pp. 786-804, 2002.

[5] R. Clarke and D. R. Collie, "Optimum-welfare and maximumrevenue tariffs under Bertrand duopoly," Scottish Journal of Political Economy, vol. 53, no. 3, pp. 398-408, 2006. 
[6] L. F. S. Wang, Y. C. Wang, and L. Zhao, "Market share delegation and strategic trade policy," Journal of Industry, Competition and Trade, vol. 9, no. 1, pp. 49-56, 2009.

[7] L. F. S. Wang and J. Y. Lee, "Partial privatization, foreign competition, and tariffs ranking," Economics Bulletin, vol. 30, pp. 2405-2412, 2010.

[8] L. F. S. Wang, J. Wang, and J. Y. Lee, "Optimum-welfare and maximum-revenue tariffs in mixed oligopoly with foreign competitors," Australian Economic Papers, vol. 49, no. 1, pp. 60-72, 2010.

[9] L. F. S. Wang, J. Wang, and L. Tang, "Tariffs ranking in mixed oligopoly with revenue constraint I," Working paper 2010, Department of Applied Economics, National University of Kaohsiung, 2010.

[10] J. Maw, "Partial privatization in transition economies," Economic Systems, vol. 26, no. 3, pp. 271-282, 2002.

[11] W. W. Chang, "Optimal trade and privatization policies in an international duopoly with cost asymmetry," Journal of International Trade and Economic Development, vol. 14, no. 1, pp. 19-42, 2005.

[12] T. Matsumura, "Partial privatization in mixed duopoly," Journal of Public Economics, vol. 70, no. 3, pp. 473-483, 1998.

[13] C. C. Chao and E. S. H. Yu, "Partial privatization, foreign competition, and optimum tariff," Review of International Economics, vol. 14, no. 1, pp. 87-92, 2006.

[14] N. Van Long and F. Stähler, "Trade policy and mixed enterprises," Canadian Journal of Economics, vol. 42, no. 2, pp. 590-614, 2009.

[15] L. F. S. Wang, J.-y. Lee, and C.-s. Huang, "Maximum-revenue and optimum-welfare tariffs in international mixed duopoly: does the order of firms' move matter?" Journal of Industry, Competition and Trade, pp. 1-11, 2011.

[16] G. De Fraja and F. Delbono, "Alternative strategies of a public enterprise in oligopoly," Oxford Economic Papers, vol. 41, no. 1, pp. 302-311, 1989.

[17] G. De Fraja and F. Delbono, "Game theoretic models of mixed oligopoly," Journal of Economic Surveys, vol. 4, pp. 1-17, 1990.

[18] Y. Katsoulacos, "Firms' objectives in transition economies," Journal of Comparative Economics, vol. 19, no. 3, pp. 392-409, 1994.

[19] K. Fjell and D. Pal, "A mixed oligopoly in the presence of foreign private firms," Canadian Journal of Economics, vol. 29, no. 3, pp. 737-743, 1996.

[20] D. Pal and M. D. White, "Mixed oligopoly, privatization, and strategic trade policy," Southern Economic Journal, vol. 65, no. 2, pp. 264-281, 1998.

[21] J. C. Bárcena-Ruiz and M. B. Garzón, "Mixed oligopoly and environmental policy," Spanish Economic Review, vol. 8, no. 2, pp. 139-160, 2006.

[22] N. Matsushima and T. Matsumura, "Mixed oligopoly, foreign firms, and location choice," Regional Science and Urban Economics, vol. 36, no. 6, pp. 753-772, 2006.

[23] K. Fjell and J. S. Heywood, "Public stackelberg leadership in a mixed oligopoly with foreign firms," Australian Economic Papers, vol. 2002, pp. 267-281, 41.

[24] T. Matsumura, "Stackelberg mixed duopoly with a foreign competitor," Bulletin of Economic Research, vol. 55, no. 3, pp. 275-287, 2003.

[25] D. Leahy and C. Montagna, "Strategic trade policy with heterogeneous costs," Bulletin of Economic Research, vol. 53, no. 3, pp. 177-182, 2001.

[26] J. P. Neary and D. Leahy, "Revenue-constrained strategic trade and industrial policy," Economics Letters, vol. 82, no. 3, pp. 409-414, 2004.
[27] T. Hatta and Y. Ogawa, "Optimal tariffs under a revenue constraint," Review of International Economics, vol. 15, no. 3, pp. 560-573, 2007.

[28] M. Yano, R. Takahashi, and J. Kenzaki, "Competition policy or tariff policy: which is more effective?" Asia-Pacific Journal of Accounting and Economics, vol. 13, pp. 163-170, 2006.

[29] C. S. Huang, J. Y. Lee, and S. S. Chen, "The optimal government shareholding strategy and the cost structure," Seoul Journal of Economics, vol. 9, pp. 251-273, 2006. 


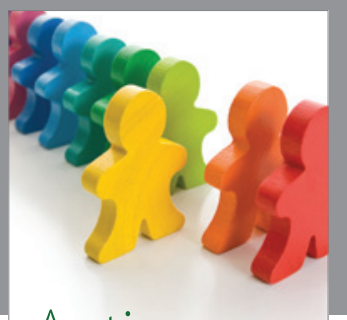

Autism

Research and Treatment
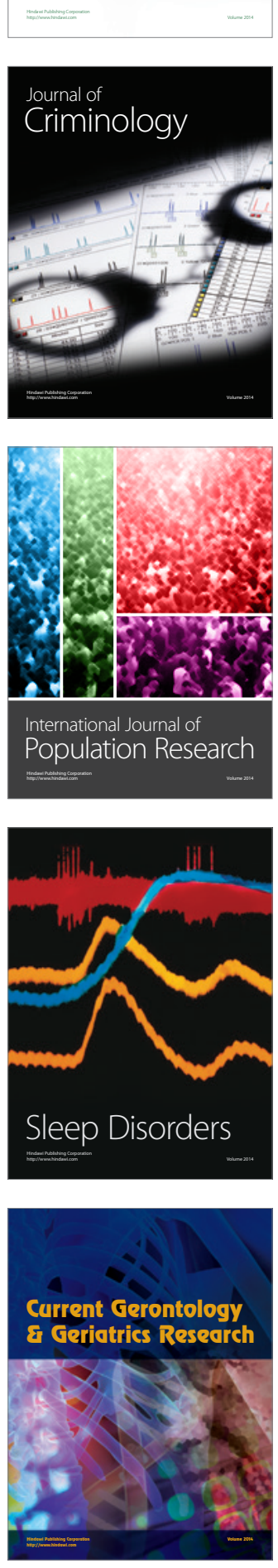
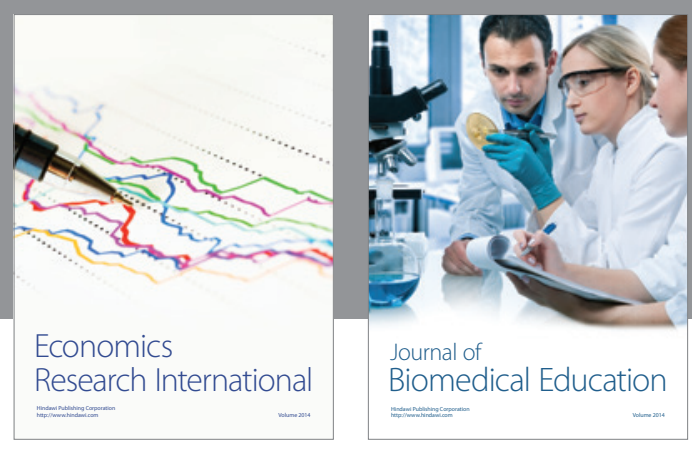

Journal of

Biomedical Education

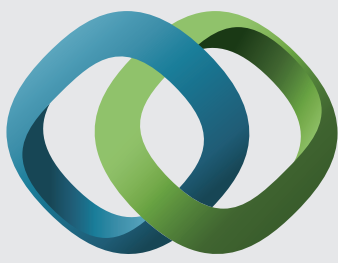

\section{Hindawi}

Submit your manuscripts at

http://www.hindawi.com
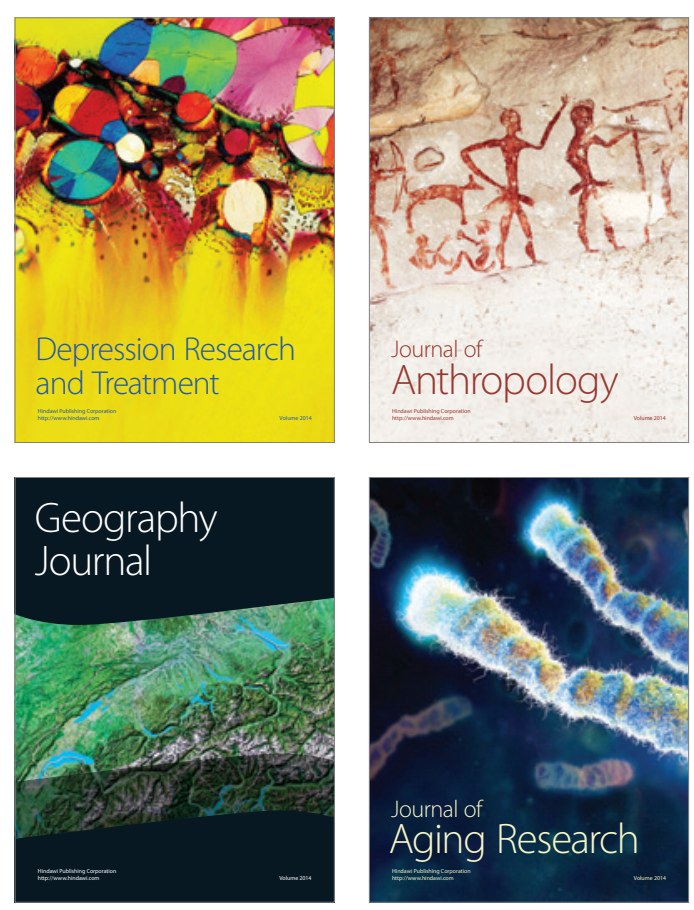

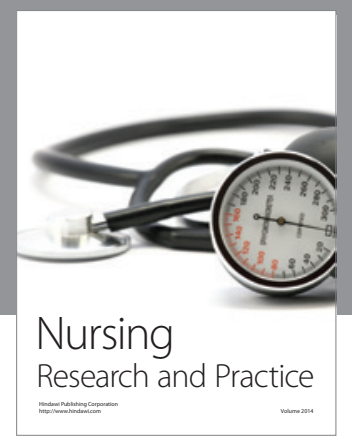

Nursing

Research and Practice

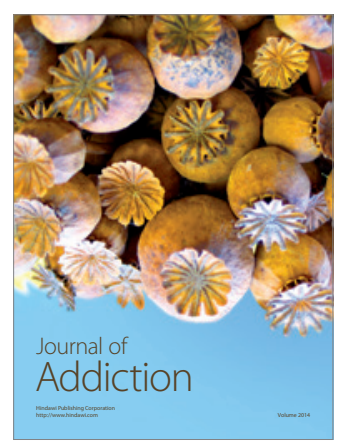

Child Development

Research

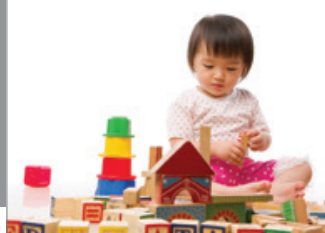

迥
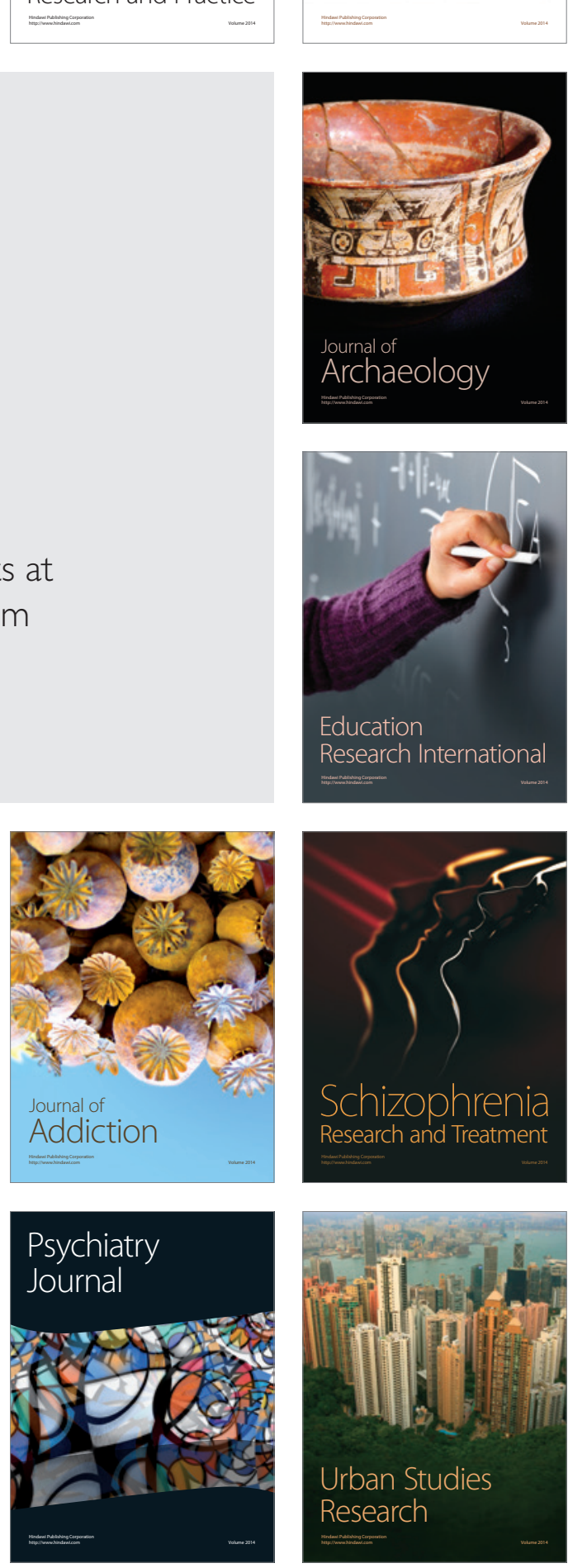